\title{
A Critical Study on Corporate Social Responsibility Activities of Public Sector Undertakings in India and its Financial implications
}

\author{
Dr Ashok kumarRath \\ Professor in Finance, Regional college of Management, Bhubaneswar.
}

\begin{abstract}
In a competitive business environment and after the implementation of Indian Companies Act-2013, acorporate entity cannot function without fulfilling its obligations towards social welfare activities known as CSR. At present the corporate houses has tobalance theireconomic and financial goalsand optimization of shareholdervalue with maximization of social benefits to the community and contributing for environmental protection. The aim of CSR is to work for developing communities and environment sustainability and to create a healthy society for the future generations. CSR includes Health, Education, Women empowerment, Environment sustainability and other activities as permitted under the Companies Act, 2013 for a better society.
\end{abstract}

Keywords- Corporate Social Responsibility(CSR),Public Sector undertakings.

\section{Introduction}

Corporate Social Responsibility refers to building the relationship with the society by theCorporate houses which may be termed as Social Relationship. Every business starts with the motive of profit making but it cannot sustain for a long period of time with this motive only . Business cannot grow when surroundings startfailing. For sustainability of business, it should have sound Corporate Governance policy. Business needs to address shareholders aswell as stakeholders which consist of suppliers, customers, creditors, the bankers, employee, and society at large. According to the report of Kumar ManglamBirla committee as appointed by the SEBI onCorporate Governance, "Thefundamental objectives of Corporate Governance are the enhancement of shareholder value,keeping in view the interest of other stakeholders".Corporate SocialResponsibility helps to address the stakeholder issues. In the age of globalized world, theconcept of CSR can't be ignored by the corporate firms. India's 10 most profitable companies will together spend Rs 2,625 crore on activitiesincluding promotion of commerce, art, science, sports, education, research, social welfare,religion, charity and protection of the environment. The spending will, preferably, have to bein the immediate vicinity of their businesses (Krishnakant, M Saraswathy, 2014). By keeping in mind the changing market scenario business firms have to change their work culture as per the market demand.Data relating to companies coming under top CSR spenders is shown in the figure-1 as given below.

Figure- 1

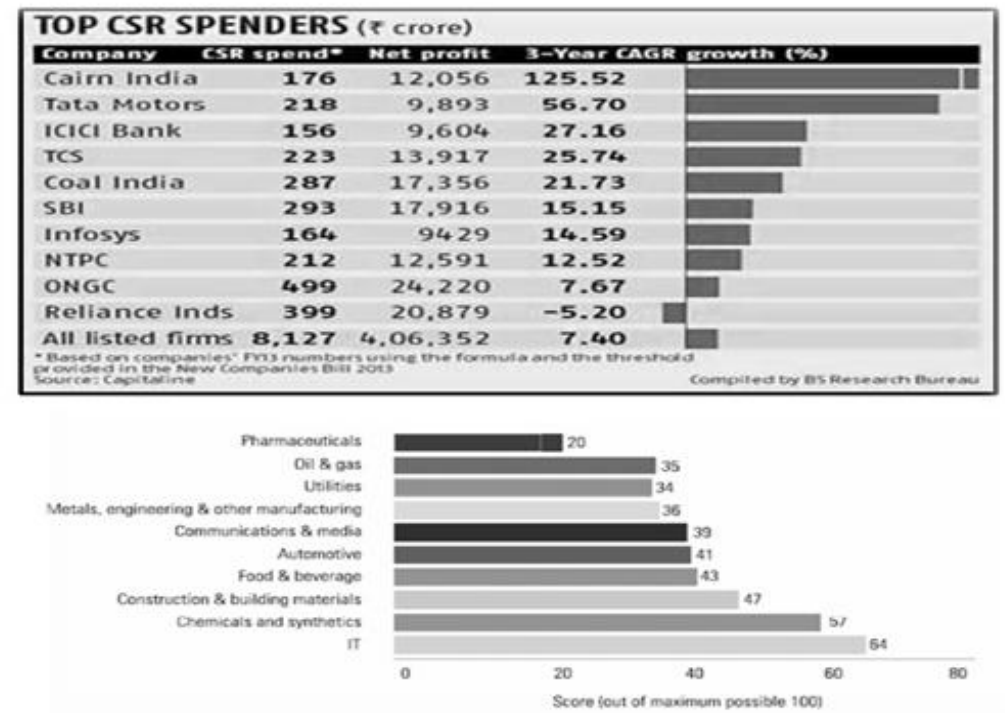

(Source :- KPMG in India, India Corporate Responsibility Reporting Survey 2013, December 2013) 
From the above data and figure it is found that in the year 2013 in India about 74 percent of discuss some social and environmental aspects of theirproducts and services. Only one in 10 reports discusses these impacts in details. Disclosureon the outcome of stakeholder engagement and actions taken is low. Only 23 percent clearlyreport on actions taken in response to feedback from all stakeholders. 32\% Indian CR reportsdoes not specify the timeliness of achievement of targets which shows the lack of commitmenttowards timely achievement (Firstpost Business, 2014). Survey clearly indicates that only16\% of the top 100 listed firms in India have a corporate responsibility strategy in place(Business Standard, 2011).

\section{Corporate Governance \& Corporate Social Responsibility}

The current situation of business world requires fromcompanies to adopt full set of corporate governance and sustainability. Before, tangible assetsand financial reports were the main concern of a company to create value for its shareholders. Now intangible assets are higher than tangible assets as percent, and concentrating switchesto non-financial reports and information affects bottom line. These changes come through implementing corporate governance and sustainability principles.CSR is a management conceptwhereby companies integrate social and environmental concerns in their business operationsand interactions with their stakeholders. CSR is generally understood as being the waythrough which a company achieves a balance of economic, environmental and socialimperatives. CSR creates bondingbetween corporation and its stakeholders.

\section{Aim of the study:}

The aim of this article is to describe the existing practices of corporate social responsibility as adopted by the Public Sector Undertakings in India. For the purpose of this study 5 Maharatna and 3 Navratna companies have been taken into consideration.

\section{Review of Literature}

Carrol A, (1999) Four characteristics of CSR: Economic, Legal, Ethical and Discretionary.Lantos(2001) arguesthatcompaniescaninvolvethemselvesinthesocialactivitiesiftheygenerateprofitfromitsgoodwork

McWilliams(2001), CorporateSocialResponsibility(CSR)hasbecomeanever-increasingandinterestingfieldof studybyresearchers andpractitioners. However,acompletedefinition ofCSRis,indeed,elusiveandopinions vary. Maignan\&Ralston (2002) awiderange of behavior sarecategorized under CSR includingcauserelatedmarketing, sponsoring charitable events, offering employee volunteerism programs, makingcharitabledonations, utilizingenvironmental initiativesanddemonstrating acommitmenttohealthand safetyissues.

Hopkins (2003)CSR is concerned with treating the internal and external stakeholders of the firm ethically or in a socially responsible manner and the wider aim of corporate social responsibility is to create higher and higher standards of living, while preserving the profitability of the corporation, for its stakeholders.

Oketch(2005)defined CSR as a function that transcends but includes making profits, creating jobs and producing goods and services.

H. Jo,M. A. Harjoto, (2012) CSR as a missing link between CG and firm performance. CG should directlyinfluence firm performance. Since, we have a conflict of interest between the two; however,CSR is acting as a conflict-resolution device between stakeholders and shareholders.

Anupam Sharma, Ravi Kiran,( 2013) in the age of globalized world, the concept of CSR can't be ignored by the corporate firms. By keeping in mind the changing market scenario business firms have to change their work culture as per the market demand.

\section{Csr In Central Public Sector Undertakings (Psus)}

Public Sector undertaking plays a crucial role in development of the nation's economy.CentralGovernment and State Government set up PSUs to build the industrial capacity andgenerating employment alongwith improving socio-economic condition. Central Governmentestablishes Central Public Sector Enterprise (CPSUs) under the Department of PublicEnterprise, Ministry of Heavy Industries \& Public Undertakings. CPSUs are governed by new guidelines issued by Department of Public Enterprise which came into effect on April 1, 2013.As per new guidelines, it is obligatory for CPSUs to disclose itsvarious CSR initiatives and performance to stakeholders. The CPSUs would have to utilizeand spend the entire amount earmarked for CSR, or would have to disclose the reasons fornot utilizing the full amount. Further, if the CPSUs are unable to spend the earmarkedamount for CSR in a particular year, it would have to spend the amount in the next twofinancial years, failing which, it would be transferred to 'Sustainability Fund'. Currently, itsimplementation mechanism is being formulated separately.In the revised guidelines, the thrust of CSR and sustainability is clearly on capacity building,empowerment of communities, inclusive socio-economic growth, environment protection, promotion of green and energy efficient technologies, development of backward regions 
andupliftment of the marginalized and under-privileged sections of the society. The revisedguidelines give a clear message that CPSUs are expected to act in a sociallyresponsible manner at all times.

\section{Financial Component for CSR}

Every year, each CPSU shall with the approval of its Board of Directors makes a budgetaryallocation for CSR and Sustainability activities / projects for the year. The budgetaryallocation will be based on the profitability of the company. More specifically, it will bedetermined by the Profit After Tax (PAT) of the company in the previous year as shown hereunder:

(i) Less than Rs. 100 Crore................... 3\% - 5\%

(ii) Rs. 100 Crore to Rs. 500 Crore......... 2\% - 3\%

(iii) Rs. 500 Crore and above............... 1\% - 2\%With the enactment of new companies act, CPSUs need not to follow above budgetaryallocation. Now they have to spend $2 \%$ of net profit under section 135 of Companies Act,2013.

Each CPSU shall have a Board level committee headed by either the Chairman and / orManaging Director, or an Independent Director to oversee the implementation of the CSRand Sustainability policies of the Company and to assist the Board of Directors to formulatesuitable policies and strategies to take the CSR and Sustainability agenda of the companyforward in the desired direction. Now as per the new law, CSR committee to be formed toformulate CSR policy and monitor itsimplementation.Corporate Governance is one of the key parameters included in the Memorandum ofUnderstanding (MoU). The government uses this as a tool to evaluate the performance of CPSUs. As a norm, CPSEs are periodically required to submit a compliance report on CSR.There are various parameters to assess the performance of CPSEs in terms of corporategovernance. The government evaluates their performance on a scale of 1 to 100. Higherscore translates into better compliance with corporate governance. If any CPSE fails tosubmit the self-evaluation or compliance report by the cut-off date, it is graded andconsidered as equivalent to 'Poor'. During FY12, out of the total 248 CPSEs, 78 CPSEs(31.5\%) received 'Excellent' score compared with 61 CPSEs in FY11, as they compliedwell with the corporate governance guidelines as shown in the figure no-2 as shown below.

Figure No-2

Grading of CPSEs: FY12 V/s. FY11

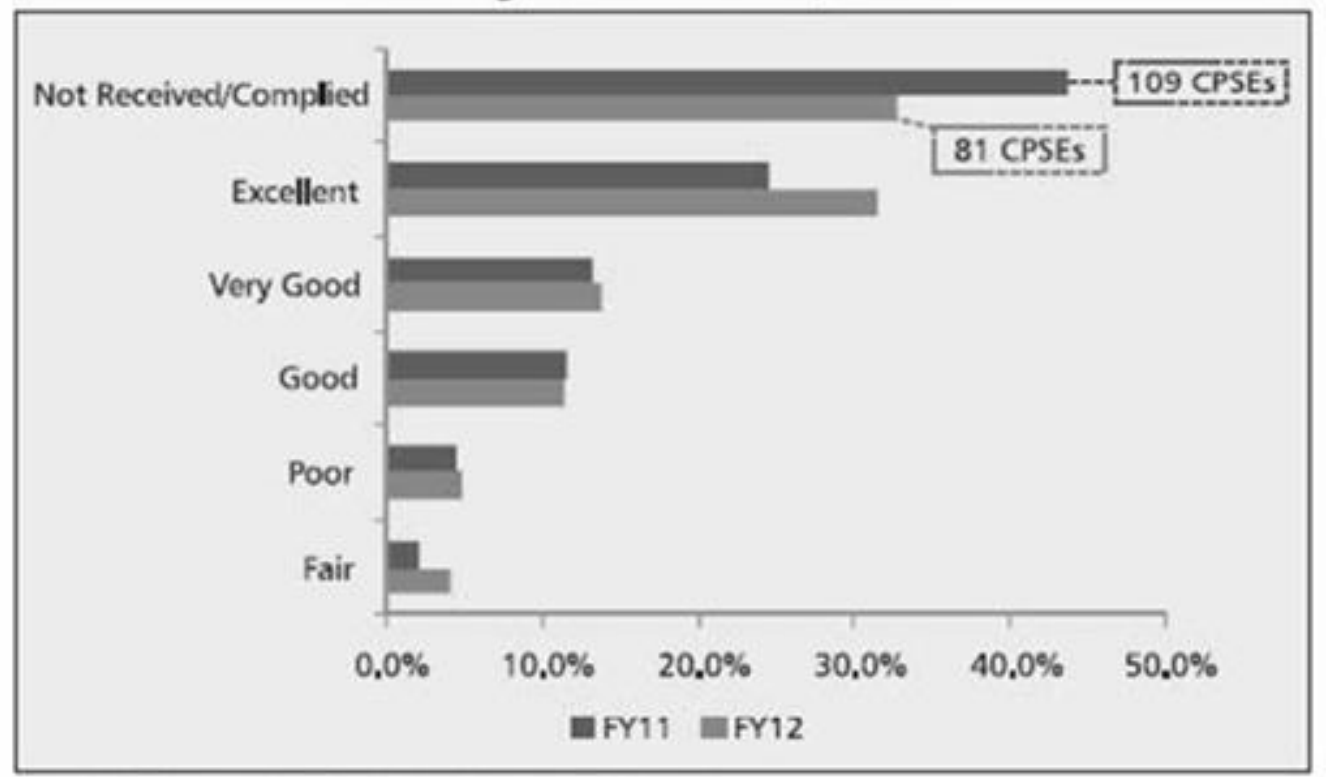

Source: Department of Public Enterprises

From the above figure it is evident that environment protection, women empowerment, andhealthcare emerged as the three major CSR activities undertaken by PSUs that offeredmaximum benefits. Around 19\% of the companies ranked environment protection as theirkey focus area that offered maximum benefit. Further, women empowerment and healthcarewere the next major CSR activities that offered maximum benefit, which the PSUsundertook. Moreover, village upliftment, education, job creation, and assistance duringnatural calamities were the other major CSR activities implemented by PSUs that providedmaximum benefits. 
Figure 3

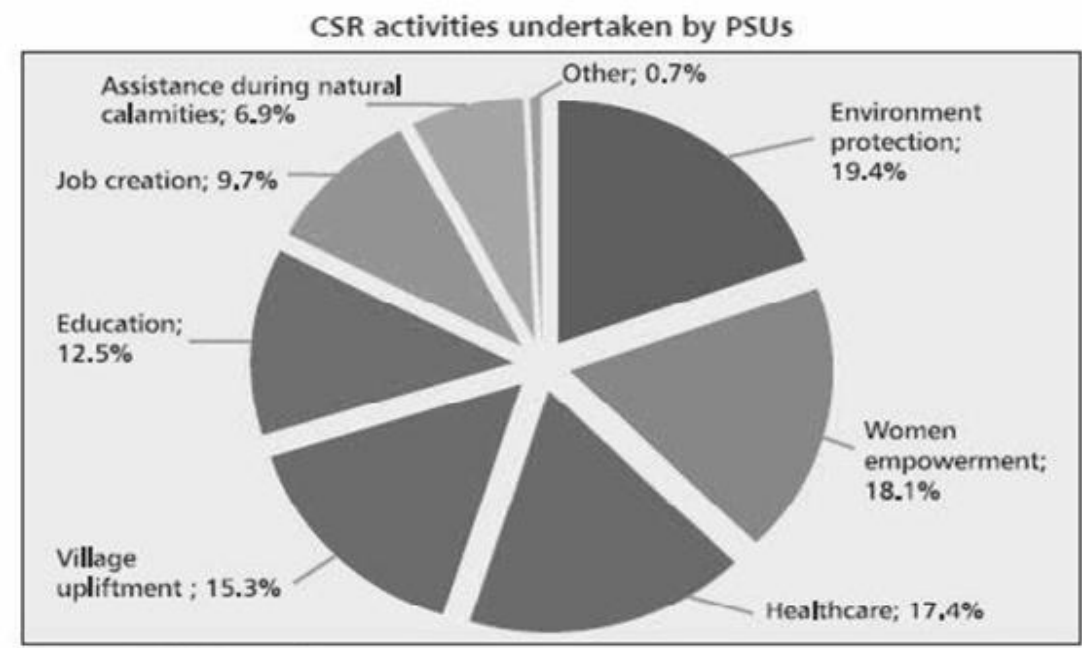

Source: D\&B Research

CSR activities undertaken by PSUs (as shown in fig-3) are facing numerous challenges and limitations while implementing CSR programs. They largely relate to the organizational level issues such as absence of a dedicated CSRteam, active involvement of key stakeholders, budgetary issues and identifying CSRprojects and their beneficiaries. It is found that identifying appropriate CSRprojects as the top-most challenge of the PSUs.This was followed by lack of active involvement of all stakeholders and beneficiaries as theother major challenge. Data shows that Maharatna and Navratnapublicsector undertakings (PSUs) have not been able to fully spend their CSR budget. Data releasedby the ministry of Heavy Industries \& Public Enterprises In the yr 2012-13 shows that the 5 Maharatnas -ONGC, Coal India, IOC, NTPC and SAIL - managed to spend just 49\% of the combinedbudget for three years beginning 2009-10. The spending budget for most PSUs is updated tillend September 2011. The combined spending of the Navratnas was higher at $65 \%$. But atleast five of these 21 PSUs managed to spend less than $25 \%$ of the CSR budget of the threeyears. Coal India spent only $27 \%$ of the budget, according to information released. National Aluminum Ltd (NALCO) was the only one that managed to fully spend its Rs 31.55 crorebudget amount. ONGC spent $49 \%$ of the budget in the three years. Whereas Coal India, itsperformance in the third year was disappointing. It spent only 6\% of the budget tillSeptember 2011. Indian Oil Corporation spent $85 \%$ of the Rs 264.4 crore it set aside andSAIL72\% of the Rs 179.68 crore. (Tina Edwin, 2012)PSUs are not taking much CSR initiatives as they don't see any support from thegovernments. Some kind of financial incentives should be given to PSUs so that they can feelmotivated and undertake more and more CSR activities. Around $60 \%$ of the surveyed PSUsfeel some kind of recognition such as receiving an award would push the level of their CSRactivities. Further, about $19 \%$ of the surveyed PSUs feel CSR expenditure should be liable fora tax deduction, which would act as a major incentive for carrying out CSR projects.

\section{Bharat Heavy Electricals Limited (BHEL)}

\section{Csr By Maharatna Companies}

BHEL has developed a CSR Scheme and its Mission Statement on CSR is " Be a CommittedCorporate Citizen, alive towards its Corporate Social Responsibility ". BHEL's contributionstowards Corporate Social Responsibility till date include adoption of villages, free medicalcamps/charitable dispensaries, schools for the underprivileged and handicapped children, banon child labour, disaster/natural calamity aid, Employment for handicapped, Widowresettlement, Employment for Ex-serviceman, irrigation using treated sewage, pollutionchecking camps, plantation of millions of trees, energy saving and conservation of naturalresources through environmental management.BHEL provides financial assistance to various NGOs/Trusts/Social Welfare Societies that arranged in social welfare activities throughout the country. 56 villages having nearly 80,000inhabitants have been adopted. BHEL shares the growing concern on issues related toEnvironment and Occupational Health \& Safety (OHS), and is committed to protectingEnvironment in and around its own establishment, and to providing safe and healthyenvironment to all its employees. For fulfilling these obligations, a Health, Safety \&Environmental Policy has been formulated and implemented through management systems. Ithas also received Prestigious Golden Peacock Award for Occupational Health \& Safety 2010. 


\section{Oil \& Natural Gas Commission (ONGC)}

The CSR initiatives of ONGC were marked by unrelenting commitment to several large -scale key projects as well as initiation of several new projects identified under the 12 focusareas of ONGC i.e.1. Education including vocational courses,2. Health Care,3. Entrepreneurship (self-help \& livelihood generation) schemes,4. Infrastructure support near ONGC operational areas,5. Environment protection, ecological conservation, promotion,6. Protection of heritage sites, UNESCO heritage monuments etc.7. Promotion of artisans, craftsman, musicians, artists etc. for preservation of heritage,Art\& Culture,8. Women's Empowerment, Girl Child Development, Gender sensitive projects,9. Water Management including ground water recharge,10. Initiatives for Physically and Mentally challenged,11. Sponsorship of seminars, conferences, workshops etc.12. Promoting Sports/sports persons; supporting agencies promoting sports / sportspersons.

ONGC, in its quest for oil and gas, charters remote rural locations and is in a constantinterface with underprivileged local communities which results in better understanding of thecommunity and consequently an enhanced sense of responsibility and accountability to thecommunities whose lives we touch.ONGC has received Golden Peacock Award founded by the Institute of Directors, New Delhifor Corporate Social Responsibility for 2013.

\section{Steel Authority of India Limited (SAIL)}

SAIL won the PSE Excellence Award - 2013 for CSR \& Sustainability in Mahartna\&Navratna category at New Delhi on December 16, 2013. SAIL recognizes that its businessactivities have direct and indirect impact on the society. It strives to integrate its businessvalues and operations in an ethical and transparent manner to demonstrate its commitment tosustainable development and to meet the interests of its stakeholders. SAIL is pioneer inimplementing CSR initiatives towards community growth and development. Education,health, income generation and sustainable development play a key role in SAIL's CSRinitiatives.On the health front, SAIL has established super-speciality hospitals and primary healthcentres, to provide specialized and basic healthcare to people living in the vicinity of itsPlants \& Units. SAIL owns, maintains and supports several schools in its steel townships toprovide modern education to children. SAIL has provided access to lakhs of people acrossvillages in its peripheries by constructing and repairing of roads. It has provided access towater infrastructure to people living in far-flung areas by installing water sources, therebyproviding drinking water access to people over the years. In order to bridge the disparitybetween rural and urban areas as also to provide comprehensive development of bothphysical and social infrastructure, many villages have been identified in 8 states as "ModelSteel Villages" for holistic development.

\section{National Thermal Power Corporation (NTPC)}

According to CMD, NTPC Ltd says "We value the partnership we build with thecommunities around our units. For us Corporate Social Responsibility is Corporate SocialRelationship".Committed socially since inception, NTPC has a comprehensive Resettlement \&Rehabilitation (R\&R) policy covering community development (CD) activities. CD activitiesin green field area are initiated as soon as project is conceived and thereafter extensiveperipheral development activities are taken up along with the project development. Aseparate CSR-Community Development Policy covers a wide range of activities starting fromunit level to regional and national level including implementation of key programmesthrough'NTPC Foundation'. Robust structure, well laid out policies and streamlined process guideour CSR initiatives benefitting more than a million people spread over about 500 villages inneighborhood of NTPC stations.NTPC has outlined four stages of CSR process i.e. (1) Planning, (2) Implementation (3)Monitoring \& Evaluation (4) Documentation \& Communication.NTPC mainly involved in Community Development activities, Education (15-20\% CSRBudget), Health, Capacity Building \& Women Empowerment, Development ofInfrastructure, Support during natural calamities, support for physically challenged person.NTPC foundation, registered in December 2004 is engaged in empowering the physicallychallenged and economically weaker sections of the society. Recently on February 8, 2014,NTPCKaniha in Orissa state organized a merit scholarship programme as a CSR initiative. InJanuary this year one day training programme for village's youth on making a career inDefence Services organized also. As a part of CSR, blankets were given away to hundreds ofDindolbhata villages near NTPC Korba super thermal power station in Chhatisgarh.NTPC has been awarded 'Greentech CSR Award 2012' in Gold Category in Power Sector byGreentechFoundation. The Greentech Awards serve as a catalyst in understanding theintrinsic value of Corporate Social Responsibility in business excellence and sustainability.NTPC has been bestowed with Golden Peacock Award for Corporate Social Responsibility(CSR) 2012 constituted by Institute of Directors (IOD), New Delhi on April 25, 2012. 


\section{Oil India Ltd (OIL)}

\section{CSR By Navratna Companies}

OIL vision statement states "OIL is a Responsible Corporate Citizen deeply committed tosocioeconomic development in its area of operations".OIL did a survey in year 1983 and based on recommendation of that company introduced ascheme entitled Social Welfare Programme in 1984 and later on another scheme called AreasDevelopment Scheme (ADS) in 1996. The SWP policy places OIL's commitment ofprotecting the environment, upliftment of education, Health and socio-economicDevelopment a topmost priority. All-round development of education, rural infrastructure,primary health care, environment protection, promotion of sports/sportsperson (especiallyrural sports), assistance to youth and women organizations in carrying out communitydevelopment activities are some of the key areas covered under SWP. Area DevelopmentScheme (ADS) was introduced in 1996 with the objective of supporting the various socio-cultural activities in the operational areas. The Scheme covers the construction of roads,setting up of educational institutions and primary health centres in the North East Region andother operational areas of the company.The World Council for Corporate Governance (WCFCG) and Centre for CorporateGovernance (CFCG) awarded Oil India with the prestigious Golden Peacock Award forCorporate Social Responsibility in 2002. Oil India Limited (OIL) also bagged the prestigiousTERI Corporate Social Responsibility Award, 2004, which was presented to OIL inrecognition of corporate leadership for good corporate citizenship and sustainable communitydevelopment initiatives. As part of a CSR initiative, energy major Oil India has decided tostep into dairy sector and has signed an agreement with Institute of Rural Management,Anand (IRMA) to carry out a feasibility study.Oil India Ltd \& Centre for SocialResponsibility \& Leadership, New Delhi, signed an MOU on 9th April, 2013 for executingAbhayanand Super 30 (an initiative of CSRL) program for providing free residentialcoaching for IIT/NIT etc. to underprivileged students of Assam and Arunachal Pradesh.Under the MOU the selected 90 students shall be provided this facility at Guwahati, JorhatandDibrugarh in Assam.

\section{RashtriyaIspat Nigam Limited (RINL)}

RINL's vision is to be a respected corporate citizen, ensure clean and green environment,develop vibrant communities.Long before the concept of CSR came into being, VSP has been in the forefront in Socioeconomic transformation. Since 1993 emphasis upon Peripheral development was put andprojects were implemented for the same under the Town Administration department. Withthe experience of Peripheral development, VSP embarked on the path of CSR after allotmentof requisite budget and fulfilling legal obligations under the Companies Act. To boost up theCSR activities, a separate Department was formed in March 2007 and RINL CSR FoundationTrust was registered under the Companies Act,1956 and IT Exemption obtained for CSR.Vizag Steel's endeavor upon Corporate Social Responsibility primarily aims at SocioEconomic development of the poor, downtrodden and marginalized sections of society andaddress the necessity to conserve the Environment. Till date, CSR activities more than 100Crores have been taken up by VSP. RINL recently organized adult women literacyprogramme in surrounding villages and tribal area of Vishakhapatnam district. Trainingprogramme was also conducted for unemployed youth to facilitate employment in securityforces. On November 29, 2013 has signed an MOU with King George Hospital to extendfinancial support for development of infrastructure by establishing Multi Storied Hospitalcomplex in KGH premises along with other CPESs. In November 2013 BalMela, a uniqueevent was conducted at Arunodaya Special Schools to bring awareness and sensitizepeople about differently abled children and the training being given to them at school.

\section{Power Grid Corporation of India (PGCI)}

PGCI is involved in Education; under this it does infrastructural development by setting upcomputer labs, library, providing sponsorship to students, mid-day meal progamme,assistance to slum dwellers' children. In health part it provides doctor \& support staff,operation of fully equipped mobile medical units, supply of ambulance, medical equipmentsetc. It has also created roads, culverts, anganwadi building, community centre, classrooms,toilets, tube wells, drinking water facilities, sewage drains etc. To solve the unemploymentproblem amongst the rural youth as well as to create a pool of skill manpower, vocationaltraining for women \& unemployed youth are being conducted in the areas of tailoring,stitching, embroidery, automobile repairing \& servicing, handloom weaving, food \& fruitprocessing, CNC lathe machine operation, welding, repairing of household electricalequipments, domestic wiring, etc. These initiatives cover the cost of training, guidance,stipend to the trainees and overall support for employment/ self-employment therebyfacilitating the socio-economic empowerment of their families. It also takes care of capacitybuilding, ecology, environment, natural calamities, progamme for differently abled person.PGCI has been conferred the "India Shining Star CSR Award" in Power Sector byWockhardt Foundation, for path-breaking CSR initiatives undertaken pan India. TheCorporation has also been awarded the Greentech CSR Award 2011 in Gold Category inPower Sector, at Srinagar, for its far-reaching CSR initiatives. 


\section{Conclusions}

From the above discussion it may be concluded that CPSWs are doing very good regarding CSR activity. They are involvedmore or less same kind of CSR activities as they follow the guidelines issued by Departmentof Public Enterprise which streamlines CSR activities of CPSEs.As per recently passed company law CSR has become mandatory for corporate as per criteriaset for that. In other words we can say that CSR has become now an integral part ofCorporate Governance. As per Section 135 of Companies Act, 2013, they have to spend $2 \%$ of the average net profit of the company made during the three immediately precedingfinancial years, in pursuance of its CSR Policy. CSR Committee to be formed for formulatingand recommending CSR policy to board, recommending amount to be spent and monitor theCSR policy time to time.Before this mandate, there were companies which were involved in CSR activity in greatersense. For them CSR is the integral part of the corporate policy. They believe in TripleBottom Line principle which leads to sustainable development. As per latest figurescompanies are spending between 1 to 2 percent for CSR activity e.g. TCS (1.60\%), CoalIndia (1.65\%), SBI (1.64\%), Infosys (1.74\%), ONGC (0.49\%), Reliance (1.91\%) etc.(Krishna Kant, M Saraswathy, 2013). All listed companies are averagely spending around $2 \%$ for CSR activities.

This new mandate will not affect the companies which are alreadyinvolved in CSR activity as their business activity and spending between 1.5 to 2 percent.They will have to spend some more on CSR to reach the level of 2 percent. It will awake thecompanies which were not doing CSR activity at all or doing minimal. Many are of theopinion that CSR should be voluntary activity but at the other hand some experts opined thatCSR must be mandatory affairs for the companies as they are affecting its stakeholders andnot taking enough care for them. By doing CSR activity they can become responsiblecompanies for the country. Referring to the issue related to CSR, IT czar AzimPremjisaidphilanthropy cannot be forced and it has to be spontaneous. Premji said the stipulation ofspending 2 per cent of profits should not become a tax at a later stage. He added that givingback to the society is important for the growth of a better world, but it should come fromwithin. (Philanthropy has to be spontaneous, can't be forced: AzimPremji, 2013). Coal Indiawhich accounts for over 80 per cent of the domestic coal production is in news for notspending its earmarked money for corporate social responsibility. It could spend merely 15 percent of the funds. Parliamentary panel has recommended that officials responsible for itmust be made accountable. The Committee also deplored the "slow action" of CIL withregard to preparing the action plan for identification and implementation of CSR projects.

Mandatory CSR policy as suggested by the new Companies Act-2013 is very good steps towards the sustainable development. We can seeCSR policy in other countries as described above, there is strong involvement of Governmentand its agency in flourishing CSR activities in the companies. Statutory obligation alone willnot help to achieve goal of CSR but collective effort from Government and Private playerssurely do that.

\section{References}

[1] Banerjee,S.B.,Lyer,E.S.andKashyap,R.K.(2003), 'CorporateEnvironmentalism:AntecedentsandInfluenceofIndustryType’,JournalofM arketing,67,pp.106-122.

[2] Bowen, H.R. (1953),Social Responsibilities of the Businessman, NewYork: Harper \& Row.

[3] Centre for Social Markets(2003), InLoura, Dr.Jitender (2014), Corporate Social Responsibility: ACaseS tudy of Selected PSU'sRole in Rural Development, International Journal of Management and Social Sciences Research (IJMSSR),Vol.3, No.2, February,p.54 [ISSN:2319-4421].

[4] Chapple,M. and Moon,J. (2005), Corporate Social Responsibility(CSR) in Asia A Seven-Country Study of CSR WebSite Reporting, BUSINESS \& Society, 44(4),pp.415-441.

[5] Chopra,S.L.(2006), TheStrategyBehindCorporateVirtue,JournalofIndianManagement,pp.92-98.

[6] Conway, C.(2003), Tracking Health and Well Beingin Goa'sMining Belt, Case Study5,Ecosystem Approach to Human Health, International Development Research Centre, Canada.

[7] Das,D.,Dhar,S.andGandhi,S.K.(2008),MandatoryDisclosureinAnnualReportsofCompaniesListedinIndianStockExchanges:Extentand Determinants, IndianAccountingReview,12 (1),pp.18-37.

[8] Dee,N.,Baker,J., Drobny,N.,Duke,K. and Fahringer,D.(1972), Environmental Evaluation System for Water Resource Planning (to Bureau of Reclamation.U.S.Departmen to fInterior), Battelle Columbus Laboratory, Columbus, Ohio, January, p. 188.

[9] Dee,N.,Baker,J.,Drobny,N.,Duke,K.,Whitman,I.andFahringer,D.(1973),AnEnvironmentalEvaluationSystemforWater Resource Planning, Water Resources Research,9(3),June, pp.523-535.

[10] Kaushik,K.P.(2007),DeterminantsofRetainedEarningsinHighlyProfitableCompaniesinIndia:AComparativeStudyofDomesticandMulti national Companies, TheICFAI JournalofAppliedFinance, TheICFAIUniversityPress,Hyderabad,13 (6),pp.19-42.

[11] KPMGand ASSOCHAM(2008), CorporateSocial Responsibility-Towardsa Sustainable Future, A White Paper [www.in.kpmg.com/pdf/csr.white paper. pdf, retrievedon $30^{\text {th }}$ March2009].

[12] Pradhan, Sanjay and Ranjan, Akhilesh(2010), Corporate Social Responsibility in Rural Development Sector: Evidences From India, School of Doctoral Studies (EuropeanUnion)Journal,pp.139-147.

[13] Saeed (2010), Corporate Social Performance of Indian FMCG Companies, Issues in Social and Environmental Accounting, 3,p. 2.

[14] Sharma, Anupamand Kiran, Ravi(2012), Corporate Social Responsibility Initiatives of Major Companies of India with Focus on Health, Education and Environment, African Journal of Basic \& Applied Sciences, 4(3), pp.95-105[ISSN2079-2034].

[15] World Business Council for Sustainable Development (1999), Corporate Social Responsibility: Meeting Changing Expectation, WBCSD Publication,p.3,GreenSweitzerland[www.wbcsd.ch/DoCROOt/hbdf197\&hmkdxBQDWW/CSRmeeting.pdf,retrievedon 7th April2009].

[16] Wood, D.J.(1991),Towards Improving Corporate Social Performance, Business Horizons, Vol.34,No.4,In World Business Council for Sustainable Development (1991),pp.66-73 